\title{
Numerical Simulation of Combined Pile-Raft Foundation under Horizontal Loading
}

\author{
Mahalakshmi M, Soundara B, Hashini C D
}

\begin{abstract}
Raft foundations generally have the ability to reduce differential settlement, contrarily causing excessive settlement. In order to overcome this, piles are used along with the raft termed as combined pile-raft foundation system. Due to the lack of availability of simplified tools and intricacy of work, the combined pile raft foundation remains as an untouched area in research. This paper explores the performance of $2 \times 2$ numerically simulated combined pile-raft foundation embedded in sand exposed to pure horizontal load using ABAQUS $3 D$. The effect of horizontal loading in terms of displacement is studied by varying the raft thickness, length and spacing to diameter ratios respectively for the combined pile-raft foundation having a pile diameter of $500 \mathrm{~mm}$. The model is validated using the existing findings. Based on this study, it is inferred that the raft thickness effect remains inconsequential whereas the length to diameter ratio and spacing to diameter ratio has an impact on the static response of the combined pile-raft foundation system.
\end{abstract}

Keywords: Combined pile-raft foundation $\cdot$ Sand $\cdot$ Horizontal loading $\cdot$ ABAQUS $3 D$

\section{INTRODUCTION}

Population migration and explosion goes hand in hand leading to rapid urbanization. This has resulted in the rise of colossal multi-story buildings and skyscrapers, where the foundation of the structure and soil plays a major role during the transfer of load. Deep foundations are generally used to withstand enormous loads and reduce settlements on soil deposits of relatively weak to moderate nature. Thus, in order to overcome the settlement and load transfer mechanism in such soils, a new technique called combined pile- raft system is used which provides an effective way to restrict the settlement to permissible limit and safe transfer of loads to the subsoil. Poulos [1] figured that the idea of combining the shallow and deep foundation was first proposed by Leonardo Zeevaert for the construction of "Tower Latino Americana" in Mexico City. Katzenbach et al. [2,3] mentioned the major design criterion to be the deformations and later marked that by considering the soil-structure interaction a safe and economic piled raft foundation can be achieved. Combined Pile raft foundation (CPRF) term was coined by Katzenbach et al. [4] which consists of pile, raft and subsoil as the load bearing elements. After idealizing the various soil profile for

Revised Manuscript Received on February 05, 2020.

* Correspondence Author

Mahalakshmi M*, Civil department, Bannari Amman Institute of Technology, Sathyamangalam, India. Email: mahalakshmim@bitsathy.ac.in

Soundara B, Civil department, Bannari Amman Institute of Technology, Sathyamangalam, India. Email: soundara@bitsathy.ac.in

Hashini C D, Civil department, Bannari Amman Institute of Technology, Sathyamangalam, India. Email: hashini.st17@bitsathy.ac.in

(c) The Authors. Published by Blue Eyes Intelligence Engineering and Sciences Publication (BEIESP). This is an open access article under the CC BY-NC-ND license (http://creativecommons.org/licenses/by-nc-nd/4.0/) combined pile raft foundation, Poulos [5,6] concluded that a uniform soil profile of relatively stiff clay or dense sand would be the favorable situations for CPRF. Analysis techniques for pile group was first developed by Butterfield and Banerjee [7] as mentioned by Randolph [8], then the analysis technique was developed for pile raft foundation by Davis and Poulos [9] and further simplified analysis methods were also developed by Hooper [10], Sommer et al. [11], Franke at al. [12], Ai et al. [13]. Another form of design approach modelled the piled raft foundation as plate loaded spring was put forth by Griffith et al. [14], Clancy and Randolph [15], Kitiyodom P and Matsumoto [16-18].

Hooper [10] first used finite element method analysis to understand the complex piled raft foundation behavior. To analyze the complex piled raft behavior one or two numerical analytical methods was combined. Ta and Small $[19,20]$, Chow and Small [21] compared Finite Element Method (FEM) and Finite Layer Method (FLM) to investigate the pile raft behavior. Burland and Kaira [22] and Prakoso and Kulhawy [23] performed plane strain 2 - D finite element analysis for elastic and elastic-plastic models to compare the settlement and to design optimum pile raft respectively. Patil et al. [24] experimentally examined the eccentrically loaded piled raft behavior embedded in sand and proposed that rafts load carrying capacity gets mount up with the addition of piles near the edges and prevent the CPRF system from tilting. In addition to the earlier works carried out on laterally loaded CPRF, a focus on the effect of static horizontal loading and its behavior is studied using numerical simulation.

\section{VALIDATION OF MODEL}

CPRF was modelled and analyzed using a finite element software ABAQUS 3D. Kumar et al. [25] has modelled a 2x2 CPRF in PLAXIS 3D using the 1-g experimentation conducted by Matsumoto [26] for a series of vertical and horizontal loading. The soil properties chosen for the experiment were based on the consolidated drained triaxial test carried out by Matsumoto et al. [27]. The present model is validated by comparing the modelling part and analysis part of CPRF under horizontal loading. The normalized lateral displacement of the present numerical model obtained was found to be in accordance with Kumar et al. [25] and hence the current numerical model can be used for assessing the performance of CPRF under different raft thickness, length and spacing to diameter ratios respectively. 


\section{Numerical Simulation of Combined Pile-Raft Foundation under Horizontal Loading}

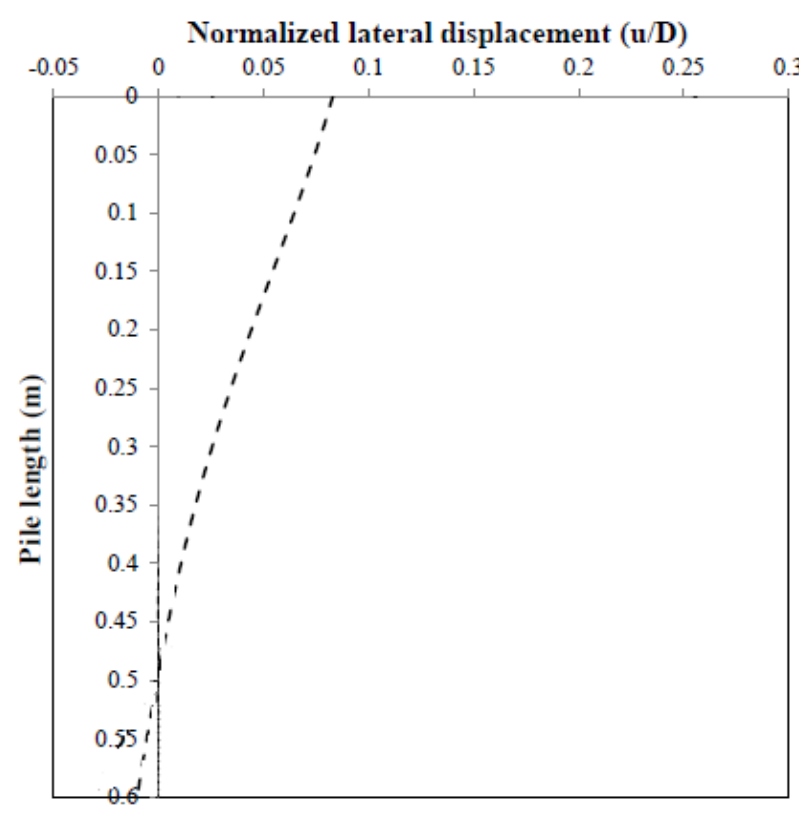

Fig. 1(a). Kumar et al. [25]

\section{Normalized Lateral Displacement(u/D)}

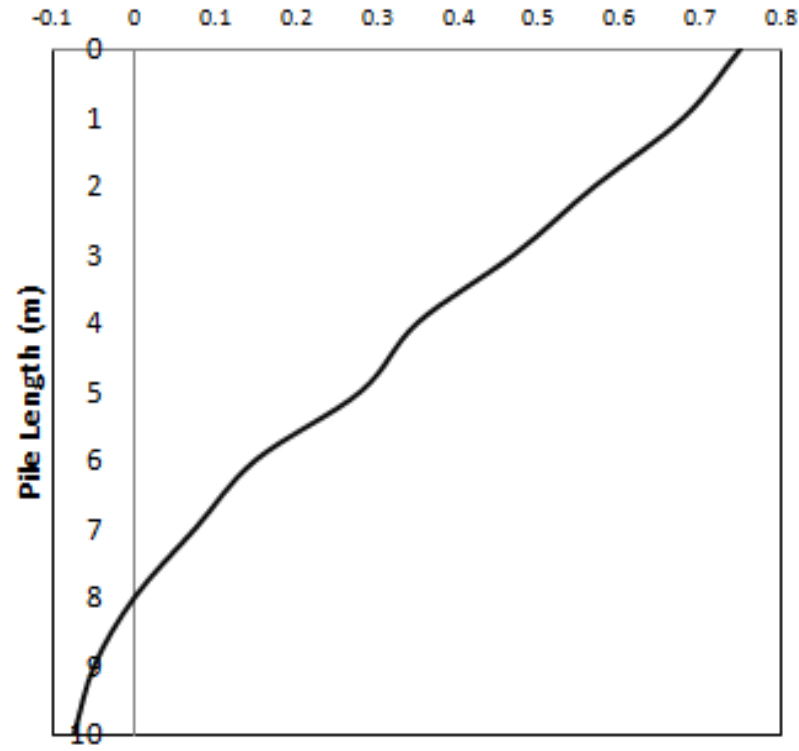

Fig. 1(b). Present Study

\section{FINITE ELEMENT MODELLING}

The static response of 2x2 Combined Pile-Raft Foundation is studied by simulating the model in a finite element software package ABAQUS 3D using the guidelines from Hibbit et al. [28]. The model consists of a soil continuum, piled raft, interaction and loadings. L/d ratios of 20, 30 and 40 were adopted terming $L$ to be the length of the pile and $d$ to be the diameter of the pile. The spacing to diameter ratio(s/d) adopted were 3, 5 and 7 where $s$ is the spacing of the piles. The variation of raft thickness was from $500 \mathrm{~mm}$ to $1000 \mathrm{~mm}$. The diameter of the pile was assumed to be $500 \mathrm{~mm}$.

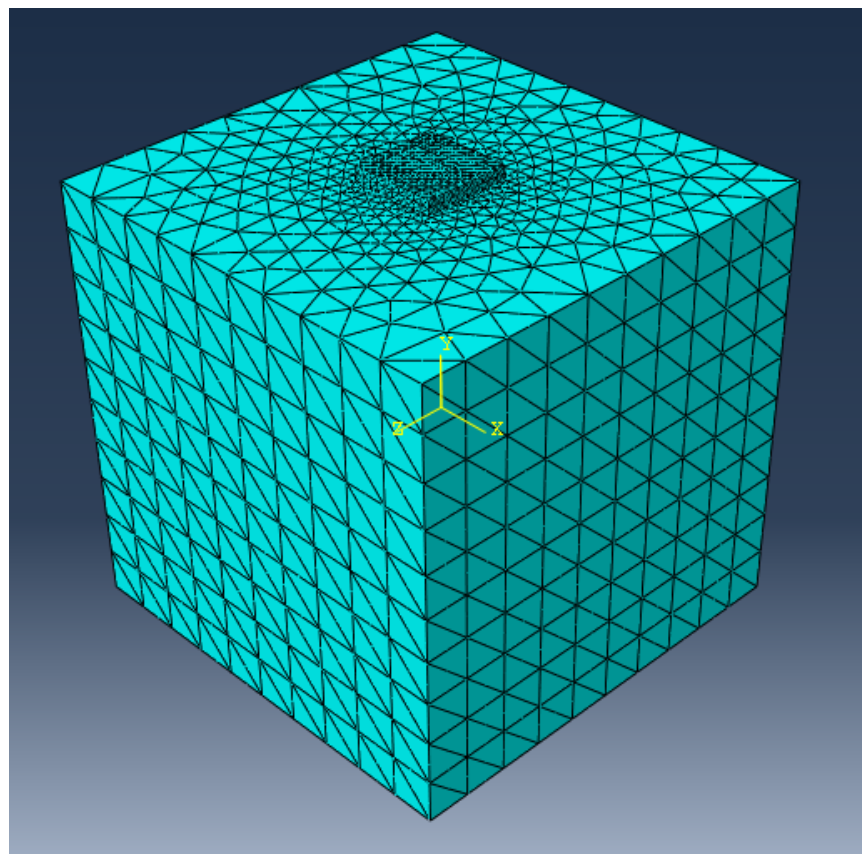

Fig. 2. ABAQUS Model

The dimension of the soil model is varied in accordance with the size of the CPRF. The soil dimension in the vertical direction was modelled in such a way that it was about 1.5 times bigger than the height of the pile as reported by Kumar et al. [29] and 5 times bigger than the width of the raft horizontally. The soil was assumed to take Mohr-Coulomb plasticity criterion and was modelled to be elasto-plastic. The modelling of pile raft was intended to be linear elastic. The soil and piled raft were modelled using 3D deformable solid parts that were extruded. The loading was given in two steps having an initial step and a static, general step.

An isotropic directional contact having a tangential mechanical behavior with a penalty type friction formulation having a coefficient of friction 0.3 was assigned. A standard surface to surface interaction with a path contact tracking was used to provide a master-slave constraint. A finite sliding formulation having no slave adjustment and surface smoothing is used to create the contact pair. The master and slave surface were the pile surface area and the element modelled as soil in contact respectively. The bottom nodes of the soil continuum were completely arrested and the side face nodes are restricted from moving horizontally. A standard element of a quadratic geometric order having a 10-node quadratic tetrahedron (C3D10) element was used.

\section{A. Study of Parameters}

The parameters chosen for the study were the effectiveness of raft thickness, length and spacing to diameter ratios respectively under horizontal loading using ABAQUS 3D. Table I defines the soil properties, pile and raft property assumed for the parametric study. 
and Piled Raft

\begin{tabular}{|l|l|l|}
\hline \multicolumn{1}{|c|}{ Property } & \multicolumn{1}{|c|}{ Soil } & \multicolumn{1}{c|}{ Piled Raft } \\
\hline $\begin{array}{l}\text { Young's Modulus E } \\
\left(\mathrm{kN} / \mathrm{m}^{2}\right)\end{array}$ & 40,000 & $4,00,000,000$ \\
\hline $\begin{array}{l}\text { Poisson's ratio } v \quad \text { no } \\
\text { unit) }\end{array}$ & 0.3 & 0.2 \\
\hline Mass Density $\gamma\left(\mathrm{kN} / \mathrm{m}^{3}\right)$ & 16.3 & 24 \\
\hline $\begin{array}{l}\text { Angle of internal friction } \\
\phi\end{array}$ & $31^{\circ}$ & \\
\hline Dilatancy Angle $\psi$ & $1^{\circ}$ & \\
\hline Cohesion $\left(\mathrm{kN} / \mathrm{m}^{2}\right)$ & 10 & \\
\hline
\end{tabular}

\section{RESULTS AND DISCUSSIONS}

\section{A. Effect of Raft Thickness}

To find the net result of thickness of raft on a CPRF, the length and spacing to diameter ratios respectively were taken as constant. The horizontal load applied on the raft acts eccentrically being the vertical loads absent. This causes an excessive deflection of the combined piled raft system. Even though the increase in raft thickness eventually upraised the load carrying capacity, but does not improve the settlement characteristics of the CPRF. The raft thickness does not remarkably reduce the settlement. This phenomenon also shows that raft is the load carrying element and hence the pile aid in reducing settlement. As shown in fig. 3(b), the change in the raft thickness does not have a larger difference in response of CPRF system which is in accordance with Oh et al. [30].

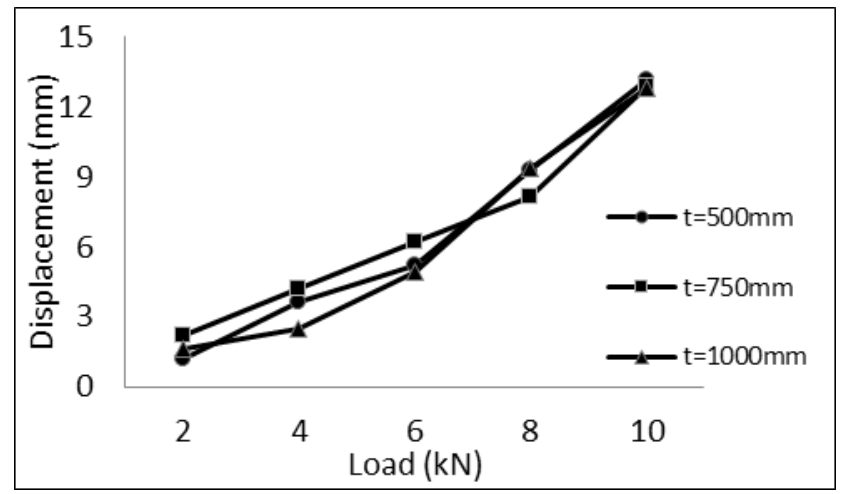

Fig. 3(a). Effect of Raft Thickness

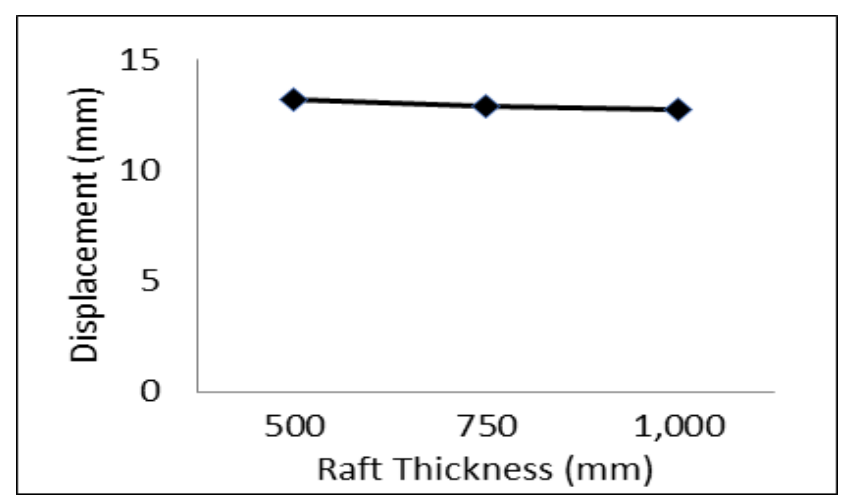

Fig. 3(b). Effect of Raft Thickness

\section{B. Effect of length to Diameters Ratios}

The length to diameter ratios that were adopted were 20, 30 and 40. For analyzing the effect of length to diameter ratios, an optimum raft thickness of $500 \mathrm{~mm}$ is used. It is notable that slender piles reduce settlement feebly on comparing to piles with smaller length to diameter ratios due to the eccentricity in loading.

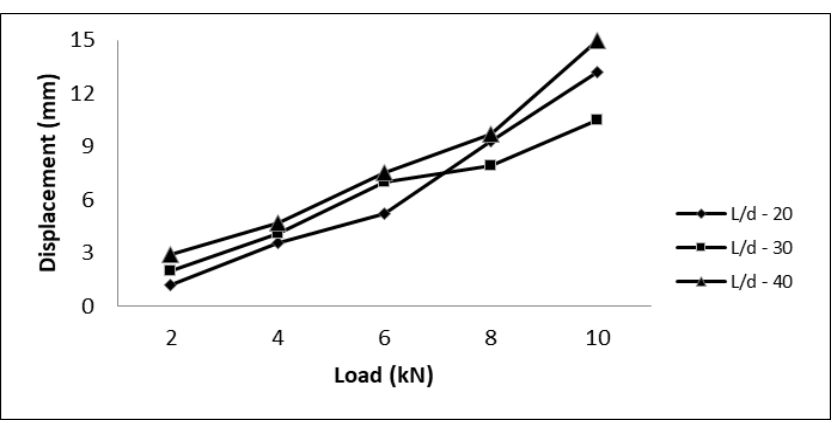

Fig. 4. Effect of length to diameter ratio

Since the loading is purely horizontal, a higher degree of eccentricity ensues while transferring load. This dictates that piles with larger length to diameter ratios are not economical to serve as settlement reducers. In the case of vertical loading, interfacial stress mobilizes at higher depths which is not applicable in our case. The length to diameter ratio has spurious claims as it has detrimental effects which are mainly due to the reduction in load carrying capacity after a certain amount of settlement. The pile group in the sand is end bearing hence the peripheral area plays only a very meagre role. The stress contour as shown in Fig. 5. shows that the stress concentration is predominant near the piled raft which is mainly due to the impact of material property. In other words, the Young's Modulus of the pile and soil affect the stress concentration.

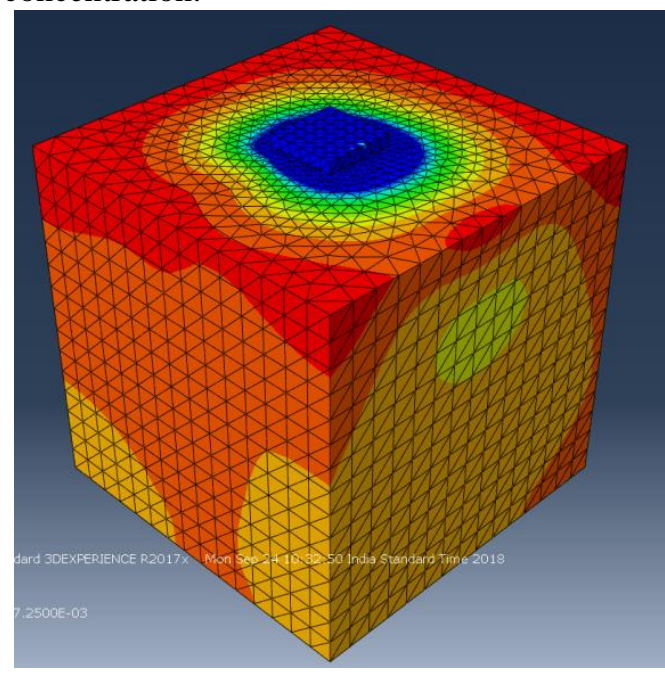

Fig. 5. Stress Contour

\section{Effect of spacing to diameter ratios}

In mandate to know the effect of spacing to diameter ratio of piles, three different spacing of $3 \mathrm{~d}, 4 \mathrm{~d}$ and $5 \mathrm{~d}$ were adopted. It is apparent that the increase in the spacing of the piles consequently increases the lateral dimensions of the raft. 
Hence, under pure horizontal loading, the raft performance is notably good when compared to that of lower spacing which may also be the consequence of the increase in load bearing volume of the raft. Although the settlement reduces as the spacing increases, the raft starts behaving like a simple mat foundation as the load transferred to the soil beneath increases thereby the interaction is loosed between the piles and they start acting like individual piles.

This shows that the raft proffers carrying load and piles the settlement reducers. The increase in spacing would be uneconomical for higher ratios as the element does not act as a combined piled raft foundation. As the spacing increases, settlement increases which are speciously due to a relatively lesser number of piles that aid in reducing settlement. The stresses in the rear pile row are found to decrease as the spacing between the piles increases which may be due to the shadow cast on the rear row which is an effect of the overlap of stresses (shadowing effect).

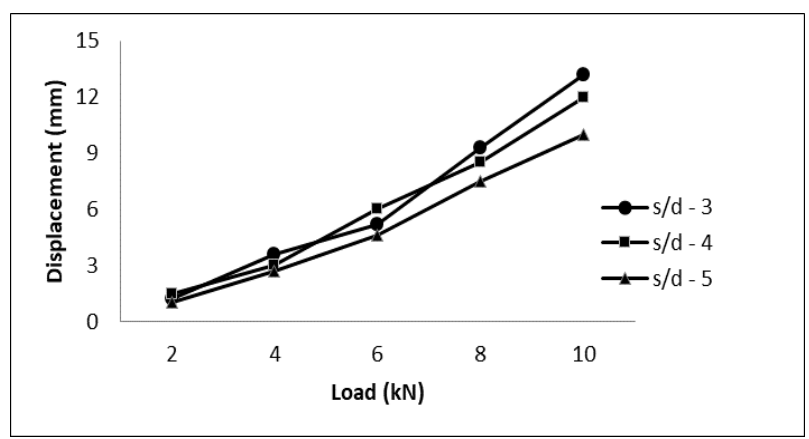

Fig. 6. Effect of spacing to diameter ratio

\section{CONCLUSION}

The static response of combined piled raft foundation under horizontal loading in the sand has been studied in this paper. Using ABAQUS 3D, the combined piled raft foundation system was modelled having a soil continuum with properties of sand using the Mohr-Coulomb plasticity model. The effect of raft thickness was insignificant in terms of displacement when subjected to horizontal loads. The consequence of the length to diameter ratios on the displacement was notable in piles having a greater length to diameter ratios as they behaved differently when subjected to horizontal loading compared to short piles which were a result of eccentricity. Likewise, the larger spacing to diameter proves to be inefficient for CPRF, since fails to validate the inception. Thus, the displacement under larger $\mathrm{L} / \mathrm{D}$ and $\mathrm{S} / \mathrm{D}$ ratios needs cautious insight so as to evade the failure due to higher stress concentration around the pile and to neglect the incompetency in the design of CPRF in terms of horizontal loading.

\section{REFERENCES}

1. Poulos HG, "Piled raft and compensated piled raft foundations for soft soil sites," Advances in Designing and Testing in Deep Foundations Engineering, Geotechnical special publication 129, ASCE, Reston,

2. Katzenbach R, and Reul O, "Design and performance of pile rafts,"Proc. XIV ICSMFE, Balkema, Rotterdam, Netherlands, 1997, 2253-2256.

3. Katzenbach R, Arslan U, and Moormann C, "Piled raft foundation projects in Germany," Design applications of raft foundations, Thomas Telford, London, 2000, 323-391. doi:10.1680/daorf.27657.0013 VA, 2005, 214-234. doi: 10.1061/40772(170)2

4. Katzenbach R, Schmitt A, Turek J, "Assessing Settlement of High-rise Structures by 3D Simulations," Computer-Aided Civil and Infrastructure Engineering. 2005, vol.20, 221-229. doi: 10.1111/j.1467-8667.2005.00389

5. Poulos HG, "Piled Raft Foundations," Design and Applications. Géotechnique 51, (2): 2001, 95-113. doi: 0.1680/geot.2001.51.2.95

6. Poulos HG, "Methods of Analysis of Piled Raft Foundations," TC18 Report, Int. Society of Soil Mechanics and Geotechnical Engineering. 2001, doi: 10.4028/www.scientific.net/AMR.838-841.334

7. Butterfield R and Banerjee P K, "The Elastic Analysis of Compressible Piles and Pile Groups, "Géotechnique 21,No.1,1971,43-60.doi:10.1680/geot.1971.21.1.43

8. Randolph M F "Design of piled raft foundations". Proc., Int.Symposium on Recent Developments in Laboratory and Field Tests and Analysis of Geotechnical Problems, 1983, 525-537.

9. Davis E H and Poulos H G , "The Analysis of Piled Raft Systems," Aust. Geomechs. J., G2: 1972, 21-27.

10. Hooper J A, "Observations on the Behavior of a Piled-Foundation On London Clay," Proceedings of the Institution of Civil Engineers E-ISSN 1753-7789 Volume 55 Issue 4, PART 2, 1973, pp.855-877. doi:10.1680/iicep.1973.4144

11. Sommer H, Wittmann P and Ripper P, "Piled Raft Foundation of Tall Building in Frankfurt Clay,". Proc.11 ICSMFE, San Francisco, 4 1985, 2253-2257.

12. Franke E, Lutz B and El-Mossallamy Y, "Measurements and Numerical Modelling of High-Rise Building Foundations on Frankfurt Clay,". Geotechnical Special Publication 40, ASCE, 2: 1994,1325-1336, New York: American Society of Civil Engineers.

13. Ai Z Y, Han J and Yan Y, "Elastic analysis of single pile-rigid circular raft system in layered soils, ". Advances in Deep Foundations, Geotechnical special publication 132, ASCE, Reston, VA, 2005, 1-14. doi: 10.1061/40778(157)24

14. Griffiths D V, Clancy P and Randolph M F, "Piled raft foundation analysis by finite elements," Proc. Int. Conf. of the International Association for Computer Methods and Advances in Geomechanics (IACMAG 91), Cairns, Queensland, Australia, (eds. G. Beer et al.), Pub. Balkema, 1991, pp.1153-1157.

15. Clancy P and Randolph M F, "An Approximate Analysis Procedure for Piled Raft Foundations,". International Journal of Numerical and Analytical Methods in Geomech., London, 17(12), 1993, 849 - 869. doi: 10.1016/0148-9062(94)91196-7

16. Kitiyodom P and Matsumoto T, "A simplified analysis method for piled raft and pile group foundations with batter piles," Int. J. Numerical and Analysis Methods in Geomech., 26(13), 2002, 1349-1369. doi: 10.1002/nag.248

17. Kitiyodom Pile and Matsumoto T, "A simplified analysis method for piled raft foundation in non-homogeneous soils,". International Journal of Numerical and Analytical Methods in Geo-mechanics; 27:2003, 85-109. doi: 10.1002/nag.264

18. Kitiyodom P and Matsumoto T, "A Simplified Analysis Method for Piled Raft Foundations Subjected to Ground Movements Induced by Tunneling,". Int. J. Numer. Anal. Meth. Geomech., 2005,29:1485-1507. doi: 10.1002/nag.469

19. Ta L D and Small J C, "An Approximation for Analysis of Raft and Piled Raft Foundations,". Computers and Geotechnics, vol. 20, no. - 2, 1997, 105-123. doi: 10.1016/S0266-352X(96)00012-2

20. Ta L D and Small J C, "Analysis of Piled Raft Systems in Layered Soils,". International Journal of Numerical and Analytical Methods in Geomech.,20, 1996, 57-72.

21. Chow H and Small J, "Settlement of a Piled Raft Foundation Considering Lateral Pile Resistance,". Computers and Geotechnics.Vol. 26, 2006, pp. 1 - 21.

22. Burland J B, Kaira J C, Queen Elizabeth II Conference Centre,Geotechnical Aspects, Proc. ICE, part I, No.- 80, 1986, 1479 1503

23. Prakoso W A and Kulhawy F H , "Contribution to piled raft foundation design, ". Journal of Geotechnical and Geoenvironmental Eng., 10.1061/(ASCE)1090-0241(2001)127:1(17), 17-24. doi: 10.1061/(ASCE)1090-0241(2002)128:8(709)

24. Patil J, Vasanwala S A and Solanki C H , "An experimental study of eccentrically loaded piled raft,". International Journal of Geotechnical Engineering 10:1, 2016 40-45.doi:10.1179/1939787915Y.0000000006 
25. Kumar A, Choudhury D and Katzenbach R, "Behaviour of Combined Pile-Raft Foundation (CPRF) under Static and Pseudo-static Conditions using PLAXIS 3D,”. 6th International Conference on Earthquake Geotechnical Engineering, Christchurch, New Zealand, 2015

26. Matsumoto T, "Implication for Design of Piled Raft Foundations subjected to Lateral Loading,". Advances in Foundation Engineering;2014, ISBN: 978-981-07-4623. doi:10.3850/978-981-07-4623-0_KN-08.

27. Matsumoto T, Fujita M, Mikami H, Yaegashi K, Arai T and Kitiyodom $\mathrm{P}$, "Load tests of piled raft models with different pile head connection conditions and their analyse,". Soils and Foundations,50(1):2010, 63-81.

28. Hibbit H D, Karlsson B L and Sorrensen P Abaqus theory manual. 2007, SIMULIA, Providence, RI.

29. Kumar M A, Deepankar Choudhury M and Katzenbach R. ASCE 04016013-2 International Journal for Geomech. 1988

30. Oh E Y N, Huang M, Surrak C, Adame R and Balasubramaniam A S, "Finite element modelling for piled raft foundation in sand. Eleventh East Asia-Pacific Conference on Structural Engineering \& Construction (EASEC-11), $\quad$ Building Sustainable Environment,Taiwan,2008 pp. 1-8.

\section{AUTHORS PROFILE}

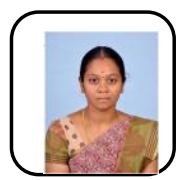

Mahalakshmi.M is working as Assistant Professor in Bannari Amman Institute of Technology Sathyamangalam, Tamilnadu.

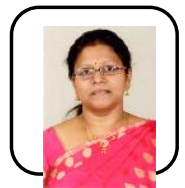

Dr.B.Soundara is working as Professor in Bannari Amman Institute of Technology, Sathyamangalam, Tamilnadu. She has published about 20 journal papers and 30 conference papers

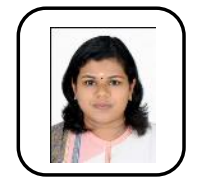

Hashini.C.D, PG student, Department of Civil Engineering, Bannari Amman Institute of Technology, Sathyamangalam 